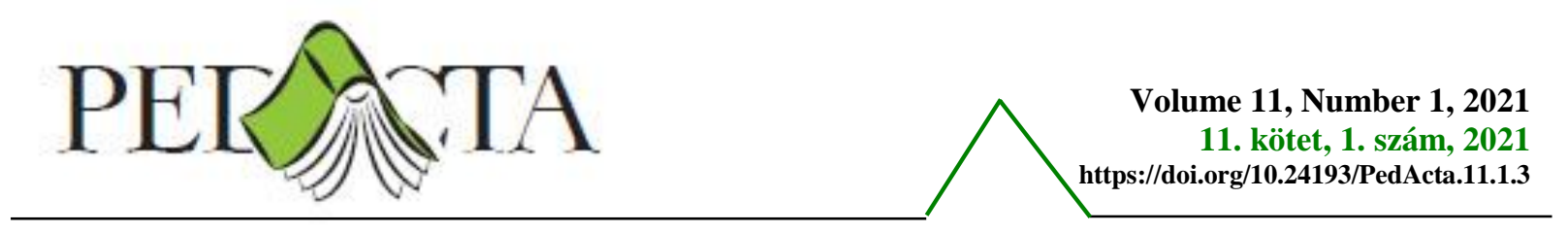

\title{
A KISISKOLÁS GYEREKEK DIGITÁLIS KOMPETENCIÁINAK VIZSGÁLATA A SZÜLŐI NEVELÉSI STÍLUS TÜKRÉBEN
}

\section{EXAMINATION OF DIGITAL COMPETENCIES OF PRIMARY SCHOOL CHILDREN IN THE LIGHT OF PARENTAL EDUCATIONAL STYLE}

\author{
Krizbai Tímea
}

\begin{abstract}
For Generation Z, online space is as natural as breathing, that is why today's children are also called digital natives, as opposed to their parents who are digital immigrants and for them, digital technology and online space do not provide as much of an experience. A healthy digital literacy is also important for healthy orientation in this online space, in the development of which the family plays an extremely important role. The present study analyses the digital competencies of primary school children in the light of parenting style and seeks to answer the question: which parenting style best supports the development of children's digital competencies. The results show that authoritative parenting style is the best ground for establishing a child's digital competencies because authoritative parents are supportive, patient, help their child, they are curious about the world they live in, so they help their children in developing competencies which helps them move around in the online space and in the world of digital "gadgets". In contrast, authoritarian parents, even if they consider digital competencies important, sometimes they use the withdrawal of digital technology as a punishment for the purpose of education, saying that this is the way they can influence their child the best. The laissez-faire parenting style is perhaps the most damaging because these parents give the child a completely free hand in accessing the online world without paying attention to the potential dangers.
\end{abstract}

Keywords: digital competences; digital literacy; digital wellbeing; parenting style.

\section{Bevezetés}

A világunk, amiben gyermekeink élnek és tanulnak, alig emlékeztet már arra a világra, amiben mi, a digitális generációt nevelő szülők nőttünk fel. Gyermekeinknek a Facebook, a WhatsApp, SMS, email már olyan kapcsolati formák, amelyek nélkülözhetetlenek. Nekünk "digitális bevándorlóknak" szokatlannak tünhet talán a mai világ (még mindig szívesen ragaszkodunk a határidőnaplónkhoz, vagy a kedvenc írószerünkhöz), míg gyermekeink számára egyáltalán nem tünik elképesztőnek az a közeg, amiben élnek. Nekik ez a természetes közeg és „,digitális bennszülöttekként”, ők egy lehetőségekkel teli, színes és dinamikus világként élik meg a mait, ahol rögtön lehet a technológia segítségével valami unalomüző, szórakoztatót látni, követni a YouTube-on, vagy bármikor csettelni barátokkal, amikor csak kedvük tarja. Szülőkként és pedagógusokként, kettős kihívás előtt állunk: nekünk kell alakítanunk a drámai változásokat, hogy a gyermekeink számára elérhetőbb világot teremtsünk, és közben úgy kell öket nevelnünk, hogy képesek legyenek ebben az egyre bonyolultabb világunkban jól 
tájékozódni, amit talán csak úgy lehetséges, ha mi magunk is tartjuk a tempót vele. Szülőként egy egészséges modellt kell mutatnunk gyermekeinknek, hogy ehhez a világhoz egészségesen viszonyulhassanak (Taylor, 2016). Ebben a korban, amikor mindannyian egyre több időt töltünk online térben, a fizikai, pszichológiai, szociális és spirituális jóllét mellett, a digitális jóllét kérdésköre is fontos lett (Diefenbach, 2018). A digitális jóllét azt a képességet jelenti, hogy tudjunk egy egészséges kapcsolatot kialakítani a technológiával, tudatosan alakítsunk ki online szokásokat, ismerjük azokat az eszközöket, amelyek segítik az egészséges technológiai szokások kialakítását és fenntartását. Ennek köszönhetően az okostelefonok menüpontjában szerepel digitális jóllétként egy olyan menüpont, ami statisztikákat mutat ki arról, hogy a felhasználó mennyi időt tölt el különböző oldalak böngészésével, illetve az alkalmazásnak szülöi felügyelet része is van és lehetőséget ad a szülőnek az ellenőrzés mellett a gyerek telefon idejének a korlátozására is. Itt válik viszont fontos kérdéssé az, hogy vajon a szülö tud-e arról, hogy léteznek ilyen fajta alkalmazások, illetve ha tud róluk, akkor felhasználja-e ezeket a gyereke nevelésében, fontosnak tartja-e a digitális jóllétet, illetve tisztában van-e azzal, hogy a túlzott okostelefonozás esetleg a gyerek mentális egészségének a rovására van? Szülőként egyensúlyt kell keressünk és teremtsünk a digitális és valós világ között, és gyerekeinknek is ezt az egészséges modellt tükrözzük. Jelen tanulmányban azt elemezzük, hogy a szülői nevelési stílus, miként hat a gyermekeik digitális tudatosságára, illetve befolyással bír-e a digitális kompetenciáik alakulásában.

\section{Digitális kompetenciák}

Amikor a kisgyerek iskolás lesz, feladata megtanulni kompetensen és hatékonyan gyakorolni a felnőttek és kortársaik által becsült készségeket, egyébként kisebbrendüség érzés alakul ki benne. Ennek az életszakasznak a krízisét Erik Erikson fejlődéspszichológus, „teljesítmény vagy kisebbrendüség" krízisének nevezte el (Cole, 2006). Hat éves korban a gyermekek megszerzik azt a „szociális intelligenciát”, amely egyaránt tartalmazza a szükséges tudást, valamint a munkavégzésnek, a társas normák betartásának és a mások iránti együttérzésnek a képességét. A hat-hét éves gyerekek már képesek bizonyos követelményeket teljesíteni. Képesek önálló feladatokat végrehajtani és célokat megfogalmazni, és megszilárdul az önuralmuk is, ezáltal képesek lesznek jobban ellenállni a kísértésnek. A gyereket az iskola, valamint a mindennapi szociális közeg, számos teljesítményre kényszeríti. Feladata ezeknek minél jobban megfelelne, önálló lenni, hogy a felnőtti világban elfogadott legyen. A játék mellett ebben az életszakaszban a gyerek olyan alapvető készségeket kell elsajátítson, mint az olvasás, írás és számolás. Ugyanakkor a lexikális tudása is egyre jobban fejlődik. Az iskola tanulás folyamatában, bizonyos kompetenciákat kell elsajátítsanak a gyerekek. Ilyen az olvasás és szövegértés, szintetizálás, következtetés, ok-okozati kapcsolatok felépítése, alapvető logikai müveletek elvégzése, az ismeretek bevésése és előhívása, tudásrendszer konstrukció. Egy másik fontos kérdés, ami az iskolában lépéssel egy időben kerül tálcára, az a digitális műveltség kérdése. A mai iskolás gyerekek a 2000 után született $Z$ generáció vagy „netgeneráció” tagjai. Nekik a számítógépes világ olyan természetes, mint a lélegzetvétel. Rengeteg tudásuk van már az iskolába lépés előtt a digitális világról (Tari, 2011). Ennek következtében egy új helyzet körvonalazódik ki, mert sem a család, sem az iskola nem zárhatja ki a digitális tudás fontosságát a szocializációs folyamatból. A szülök és pedagógusok figyelembe kellene vegyék a gyerek online terét is az offline tér mellett. Egy olyan társadalomban, ahol a kisiskolásokat rengeteg információ bombázza minden csatornán, egyik legfontosabb társadalmi feladatunk, megtanítani, szelektálni az őt bombázó információk között és tudatos digitális állampolgárrá nevelni. Ugyanazok a tanulási kompetenciákat, amelyeket régen csak az offline környezetben kellett elsajátítson, most az online környezetben is meg kell tanulja használni. A digitális technológia által alátámasztott oktatási rendszerben a tanuló kompetenciái is változnak. Fontos a kreativitás és innováció, a digitális média és a digitális környezet használata kommunikációra és együttmüködésre, a digitális eszközhasználat információgyüjtésre, kritikai gondolkodás, problémamegoldás, döntés, hogy a megfelelő digitális eszközöket használják a problémamegoldó folyamatban. Fontos tehát, hogy a gyereknek legyen egy digitális müveltsége, vagy úgynevezett „digitális tolltartója” (Ollé, 2013). A digitális müveltség alapvető létszükségletté és kompetenciává vált, amelynek hiánya akadályozza a társadalmi beilleszkedést és a személyes fejlődést. A nem megfelelő információs-kommunikációs technológiai felkészültséggel rendelkezők, hátrányos helyzetbe kerülnek sok esetben. Az Európai Bizottság jelentésének munkadefiníciója a következö 
(2010): a digitális müveltség mindazoknak a jártasságoknak az összessége, amelyek a digitális kompetencia megszerzéséhez szükségesek. Ilyen az alapvető IKT-jártasság, illetve a számítógéphasználat (visszakeresés, hozzáférés, megőrzés, létrehozás, bemutatás, információcsere, kommunikáció, közösségi hálózatokban való részvétel képessége az interneten keresztül). A nemzetközi szakirodalomban bontakozott ki az utóbbi években egy olyan fogalom, hogy „digitális állampolgárság” fogalma (2011). Ohler (2010) modellje szerint a tanulókban a digitális eszközöknek köszönhetően kettős világ alakult ki. Az egyik világ a természetes környezet, vagyis az offline tér, a másik az online tér, az a digitális világ, amiben mozognak. A két világ különválasztása nem a legegészségesebb, mert konfliktusokat és megoldásokra váró új problémákat generál. A leghasznosabb az integrált szemlélet, amelyhez nem elegendő az egyszerú eszközhasználatról való gondolkodás, hanem a digitális állampolgárság fogalmának értelmezése szükséges.

\subsection{A szülői nevelési stílus}

A gyermek szocializációjának egyik legjelentősebb színtere a család, kiemelten a szülő-gyermek kapcsolat, amely a személyiségfejlődést különböző területeire hatással van. A hazai és nemzetközi szakirodalomban számos, a szülői nevelési stílust feltérképező tanulmány született. A legtöbb tanulmány a Schaefer-féle (1959) tipológia köré szerveződik. Becker és Schaefer szülői attitüdökről felállított modellje két dimenzióval írja le a szülők magatartását és annak hatását a gyermek személyiségére. Az érzelmi dimenzió, a szülő érzelmi viselkedését írja le, a két végpontja a meleg és hideg szülöi attitüdre vonatkozik. A meleg szülői viselkedés a gyermeket elfogadó, támogató, megértő magatartás, míg a hideg ennek az ellentéte (Ranschburg, 1998). Becker (1964) a szülői szeretetet a büntetés módjával kapcsolja össze. A meleg, elfogadó szülö a büntetéskor inkább dicséretre alapoz, magyarázattal formálja a gyerek viselkedését, a gyerek viselkedését értékeli és nem a személyiségét, mindeközben a gyereket biztosítja arról, hogy akkor is szereti, ha éppen nem elfogadható a viselkedése. Ezzel szemben a dimenzió hideg, elutasító végpontja közelében elhelyezkedő szülő a hatalmát hangsúlyozó büntetési módokat alkalmazza, pl.: kiabálás, megszégyenítés, fizikális büntetés (Vajda és Kósa, 2005). A kontroll dimenzió arra vonatkozik, hogy a szülő mennyire szorítja korlátok közé a gyerek szabadságát, a szülő milyen és mennyi szabályt állít fel a gyerek viselkedésének szabályozására. A dimenzió engedékeny végpontja olyan szülői magatartást ír le, amelyik szabad utat ad a gyerek viselkedésének, míg a korlátozó végponthoz közel álló szülő fékezi a gyerek viselkedését, merev rendszabályokat állít elé (Ranschburg, 1998; Vajda és Kósa, 2005). A két dimenzió egymástól független, a modell a dimenziók kombinációjával írja le a szülő nevelési magatartását és hatásait a gyermek személyiségére.

1. táblázat: Becker modellje (Forrás: Vajda és Kósa 2005, 225)

\begin{tabular}{|c|c|c|}
\hline & Elfogadó szülő & Elutasító szülő \\
\hline Kontrolláló szülö & $\begin{array}{c}\text { Szabály- és tekintélytisztelő, dependens, } \\
\text { konformista, kevésbé kreatív, lelkiismeretes }\end{array}$ & $\begin{array}{c}\text { Szorongó, barátságtalan, } \\
\text { boldogtalan, neurotikus hajlam, } \\
\text { szuicid veszély }\end{array}$ \\
\hline Engedékeny szülő & $\begin{array}{c}\text { Barátságos, non-konform, kreatív, } \\
\text { kezdeményező, vezető }\end{array}$ & $\begin{array}{c}\text { Nyílt agresszió, a morális } \\
\text { szabályzórendszer hiánya, } \\
\text { antiszociális }\end{array}$ \\
\hline
\end{tabular}

Baumrind (1991), Becker és Schaefer modelljére építkezve három különböző nevelési stílust különített el.

A tekintélyelvü (autoriter) szülö: A szülő kontrollálja és értékeli a gyerek viselkedését a saját normái alapján, amelyeket ő dönt el, és nem veszik figyelembe a gyerek igényeit. A szülő magas elvárásokat támaszt a gyerekkel szemben, és nehezem fogadja el, ha a gyerek viselkedése nem felel meg ezeknek az elvárásoknak. A gyerektől engedelmességet követel, elvárja a tekintély tiszteletét. A szabályok megkérdőjelezhetetlenek, a szülő szigorúan betartatja, de nem fordít figyelmet arra, hogy a gyerek megértse a szabályok értelmét. A szülő érzékenysége, válaszkészsége a gyerek igényeire alacsony. 
Az engedékeny szülő: Meleg, elfogadó attitüd jellemzi. Nagyobb autonómiát biztosít a gyereknek, és nem szólítja meg egyfolytában a helytelen viselkedésért. Alacsony elvárásai vannak a gyerekkel szemben, és nem bünteti meg a nem megfelelő viselkedését, hanem jól tolerálja azt. Elfogadó a gyerek vágyaival, viselkedésével és impulzusaival szemben. A gyerek viselkedését kevésbé kontrollálja, alakítja, és ez gyakran párosul a gyerek fejlődése iránti alacsony érdeklődéssel.

A mérvadó (autoritatív) szülő: A szülő elismeri, hogy a gyereknek a kötelezettségei mellett jogai is vannak. Habár a szülőnek magas elvárásai vannak a gyerekkel szemben, de ez meleg, támogató attitüddel párosul. A szülő segíti a gyereket az önállóságban, függetlenségben, de ugyanakkor a normák betartására, konformitásra neveli. Irányítja és kontrollálja a gyerek viselkedését, de válaszkészsége a gyermek igényeire nagy, gyakori a szülő és gyermek közötti interakció. A szülő felelősségteljes és elkötelezett a gyerek viselkedése iránt. Baumrind (1991) szerint a legoptimálisabb nevelési stílus az autoritatív stílus. Longitudinális vizsgálataiban a szerző azt találta, hogy azok a gyerekek, akik mérvadó nevelési stílusban részesültek, a kognitív és szociális kompetenciái, a verbális és matematikai teszteken elért eredményeik magasabbak voltak, mint a másik két nevelési stílusban részesülő gyerekek eredményei.

\section{A kutatás célja és hipotézisei}

A jelen vizsgálat célja, kisiskolás gyerekek csoportjában a digitális kompetenciák, illetve eszközhasználati szokások mérése. Ugyanakkor összefüggések keresése a szülök nevelési stílusa, valamint gyerekük eszközhasználati szokásaik és digitális kompetenciáik fejlettsége között.

\subsection{A kutatás hipotézisei}

- Feltételezhető, hogy minél nagyobb életkorú egy gyerek, annál fejlettebbek a digitális kompetenciái és eszközhasználati képességei.

- Feltételezhetö, hogy annak ellenére, hogy egy gyermek elég jól kezeli már a technológiát, nem feltétlenül képes a káros hatások szürésére (pl. nemkívánt reklámok kikapcsolására).

- Feltételezhetô, hogy a mérvadó nevelői stílus hatására a gyerekek digitális kompetenciái a legoptimálisabban fejlődnek, vagyis a gyermek tudatosabb eszközfelhasználó lesz és jobban tudja az offline és online tért egyensúlyozni.

\section{Módszerek és eszközök}

A vizsgálatot a brassói Momo Ház - személyiségfejlesztő központba járó gyerekek és szüleik csoportjában végeztük (www.momocenter.ro). A Momo Házban dolgozó szakemberek évente indítanak egy digitális müveltséggel és médiafogyasztással kapcsolatos fejlesztő programot, ahol a gyerekek egy tanéven keresztül heti rendszerességgel, alternatív pedagógia módszerekkel tanulnak meg olyan hasznos digitális kompetenciákat, amelyek segítik őket egészséges eligazodni az online térben. A tanulási folyamatba a szülők is bekapcsolódnak és a digitális modul keretén belül, interaktív workshopokon vesznek részt, melynek célja, hogy szülőként, hogyan neveljenek tudatosan és egészséges müködő digitális nemzedéket. A foglalkozásokra beiratkozott gyerekek első lépésben egy összetett kérdőívet töltenek ki a szakemberek segítségével, amely az eszközhasználati szokásaikról szól, illetve arról, hogy különböző eszközökön, milyen müveleteket tudnak végrehajtani pl. visszakeresés, hozzáférés, megőrzés, létrehozás, bemutatás, információcsere, kommunikáció, közösségi hálózatokban való részvétel képessége az interneten keresztül. Ugyanakkor a szülők is (általában az anya a kitöltő) kitöltenek egy kérdöívet a gyerekeik és saját eszközhasználati szokásaikról, valamint a szülői nevelési stílusukról. A jelen tanulmány ezeknek az előméréseknek az adatait mutatja be, melyek 2019 és 2020 szeptemberében kerültek felvételre. Mivel a vizsgálatban kiskorú gyerekek vettek részt, aláírattunk a szülőkkel egy beleegyezési nyilatkozatot is.

A gyerekek digitális kompetenciáinak feltérképezésére a www.eukidsonline.net oldalon közzétett kérdéscsomagokat használtuk fel. Az EU Kids Online egy multinacionális kutatási hálózat és platform. Célja az európai gyermekek online lehetőségeinek, kockázatainak és biztonságának megismerése. 
Többféle módszert alkalmaz a gyermekek és a szülök internetes tapasztalatainak feltérképezésére, párbeszédben a nemzeti és az európai politikai érdekeltségü felekkel. Az EU Kids Online, a Global Kids Online kezdeményezés egyik együttműködő partnere, egy nemzetközi kutatási hálózat, amely jelenleg 33 országot foglal magában. Célja annak összehangolása és ösztönzése, hogy a gyerekek miként használják az új médiát Európában, különös tekintettel az online kockázatokra és biztonságot alakító feltételekre vonatkozó bizonyítékokra. A digitális kompetenciákat feltérképező kérdések az internethasználati szokásokra kérdeztek rá (mennyit, mikor és hol), arra, hogy milyen digitális eszközei vannak a gyereknek, mióta használja ezeket, milyen helyzetekben és kitől kér segítséget a digitális eszközökön való tájékozódásban, milyen online tevékenységeket végez a gyerek, milyen digitális képességekkel rendelkezik (pl. ismeri a biztonsági beállításokat, letölt anyagokat, lementi, visszatalál arra a honlapra ahol már járt), milyen szinten tudja használni az okoseszközöket.

A szülői nevelési stílus felmérésére a Baumrind nevelési stílus standardizált kérdőívének magyar adaptációját használtunk (Parenting Practices Questionnaire, Baumrind, 1991). Baumrind (1991) kérdőíve 62 itemet tartalmaz, és az édesanya tölti ki a kérdőívet a maga és az apa nevében. Minden kérdésre a kitöltő egy 5 pontos Likert skála alapján válaszol a maga és szülőtársa nevében. A kérdőív a három nevelési stílus térképezi fel. A mérvadó nevelési stílusnak, négy alfaktora van: bevonódás/melegség; rávezetés/magyarázás; demokratikus részvétel; türelmesség/nyugodtság. Az autoriter nevelési stílusnak szintén négy alfaktora van: verbális hosztilitás; fizikai büntetés; önérvényesítő magatartás; direktvitás. Az engedékeny nevelési stílusnak három alfaktora van: következetesség hiánya; nem megfelelő viselkedés ignorálása; önbizalom.

\section{Vizsgálati populáció}

Amint azt a módszerek és eszközök részben részletesen ismertettük, a vizsgálati populációt a brassói Momo Ház - személyiségfejlesztő központba beiratkozott gyerekek és szüleik csoportja képezte. Összesen 40 gyerek (19 fiú és 21 lány) és 40 szülő töltötte ki a kérdőívcsomagot. A nevelési stílus kérdőívet az édesanyák töltötték ki saját maguk és szülőtársuk nevében. A vizsgálatban részt vett édesanyák életkora 34 - 43 év közötti volt, átlagéletkoruk 37 év volt. A kérdőívet kitöltő szülő 64,4 \%nak felsőfokú végzettsége volt. A gyerekek életkora 6-10 év közötti volt, az átlagéletkor 8 év volt.

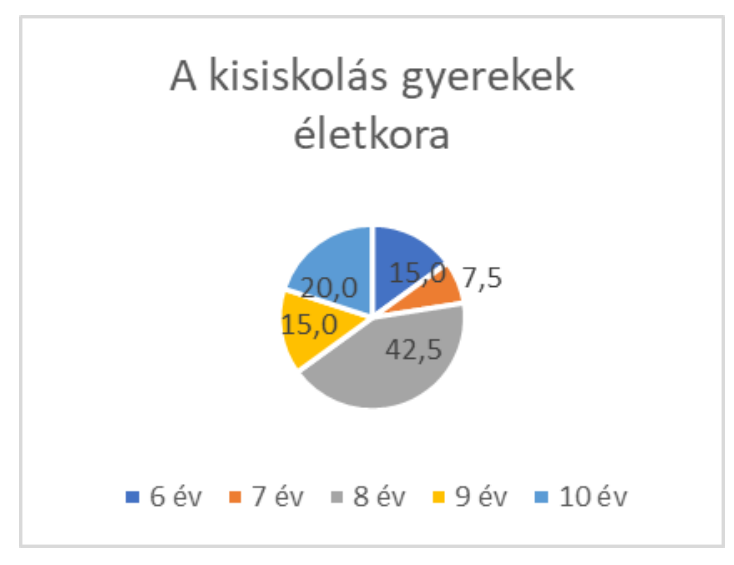

1. ábra. A kisiskolás gyerekek életkora

\section{Eredmények}

\subsection{Internethasználati szokások és digitális kompetenciák}

A kisiskolás gyerekek 67,5\%-nak van saját okostelefonja. A vizsgálatban részt vett minden 10 éves gyereknek van saját okostelefonja, a 9 évesek 66,7\%-nak van, a 8 évesek 64,7\%-nak, a 7 és 6 éveseknek nincs saját telefonjuk, viszont a szüleik telefonján nekik is van online idejük. A gyerekek 42,5\%-a napi szinten használja az Internetet. Az életkor ebben az esetben is meghatározó, a 6-7 évesek ritkábban, a 8-10 évesek már naponta használják az Internetet. Közösségi oldala 2 gyereknek van, 
ezek a gyerekek 10 évesek, habár a közösségi oldalaknál 13 év a felhasználói életkor. A 2-es ábrán látható, hogy a gyerekek hétvégén többet használják az Internetet, mint hétközben, amikor iskolai feladatokra kell koncentrálniuk. Hétközben 38,7\%-uk csak keveset Internetezik, ami azt jelenti, hogy kevesebb, mint egy órát és hétvégén pedig 41,9\%-nak több, mint egy órát meg van engedve, hogy az online térben navigáljanak.

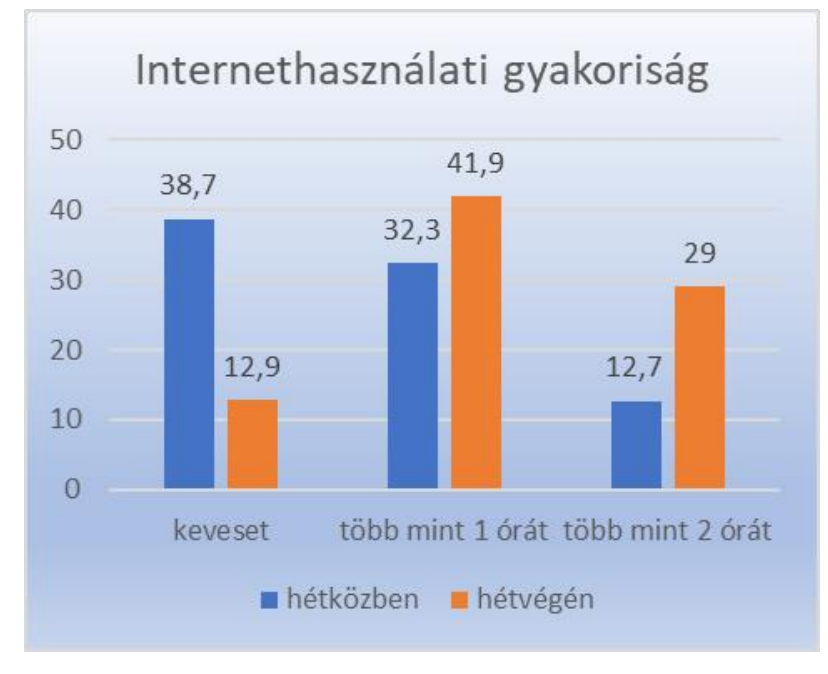

2. ábra. A gyerekek internet-használati gyakorisága hetente, illetve hét közben

A gyerekek nagyrésze, 51,2 \%-a az online tevékenységek során YouTube videókat nézeget, online játékokat játszik egyedül 12,5\%-a, rajzfilmet néz 22\%-a, csettel a barátokkal és családtagokkal 7,8\%a és 6,5\%-a közösségi oldalakon nézelödik.

A 2-es táblázatból leolvashatóak a gyerekek digitális kompetenciái életkorra lebontva. Az online információhoz való hozzáférés a 7-10 éves gyerekeknek 100\%-ban sikerül, tehát tudják, hogy hogyan kell megtalálni információkat az internetet. Csupán a 6 évesek szorulnak még segítségre akkor, amikor az Interneten kell keresgéljenek, főleg amiatt is, hogy nincs az írás készségük még kialakulva. A létrehozás képessége a 6-8 évesek körében még nem teljesen kialakult, vagyis még nehézségeik vannak a tartalmak létrehozásában (fénykép/video/szöveg) és ezek interneten való megosztásában. A 9-10 éves gyerekeknek ez a kompetencia is ügyesen megy már. A visszakeresés képessége az életkorral nő, viszont hajlamosak a gyerekek elbóklászni az Interneten és nem mindig tudnak visszatalálni arra az oldalra, ahonnan elindultak. Függetlenül az életkortól, úgy a 6 éves, mint a 10 éves gyerek könnyen megtanulja, hogy hogyan kell egy játékot telepíteni az okostelefonra, táblagépre, felismerik a play áruház logóját és a kicsik, annak ellenére, hogy nem tudnak olvasni, mégis a jelek alapján követik a lépéseket és sikeresen telepítenek alkalmazásokat vagy játékokat (!). A megőrzés képessége is az életkorral fejlődik, viszont még a 10 évesek sincsenek teljesen tisztában azzal, hogy bizonyos online tartalmakat, hogy lehet lementeni és tárolni, szervezni az okostelefonon, táblagépen vagy akár laptopon/asztali számítógépen.

2. táblázat. A kisiskolások digitális kompetenciáinak százalékos kimutatása életkorra lebontva

\begin{tabular}{|c|c|c|c|c|c|c|}
\hline & $\begin{array}{c}\text { Digitális } \\
\text { kompetenciák }\end{array}$ & $\mathbf{6}$ év & $\mathbf{7}$ év & $\mathbf{8}$ év & 9 év & $\mathbf{1 0}$ év \\
\hline 1. & Hozzáférés & $66,7 \%$ & $100 \%$ & $100 \%$ & $100 \%$ & $100 \%$ \\
\hline 2. & Létrehozás & $33,6 \%$ & $66,7 \%$ & $72,3 \%$ & $100 \%$ & $100 \%$ \\
\hline 3. & Visszakeresés & $16,3 \%$ & $33,3 \%$ & $76,5 \%$ & $50 \%$ & $87,5 \%$ \\
\hline
\end{tabular}




\begin{tabular}{|c|c|c|c|c|c|c|}
\hline 4. & Telepítés & $100 \%$ & $100 \%$ & $100 \%$ & $100 \%$ & $100 \%$ \\
\hline 5. & Megőrzés & $16,7 \%$ & $66,7 \%$ & $41,2 \%$ & $51,2 \%$ & $87,5 \%$ \\
\hline
\end{tabular}

A 3-as táblázat a kisiskolások mobiltelefonhasználati képességeit mutatja be. 7 évestől kortól a kisgyereknek teljesen ismerős a wifi fogalma és semmilyen akadálya nincs annak, hogy egy telefonnal a wifi-re kapcsolódjon. A nagyobb gyerekek, 8-10 évesek már azt is megtanuljak, hogy hogyan védjék le a telefonjukat PIN kóddal. A komplexebb parancsokat viszont nehezen értik és alkalmazzák. Például nem tudják a nemkívánt alkalmazásokat letiltani, illetve a 6 évesek az alkalmazások zavaró üzeneteit sem tudják lekapcsolni. A telefon helyazonosító földrajzi funkcióját is csak a nagyobb gyerekek tudják kikapcsolni, a kisebb gyerekek nem is értik, hogy ez pontosan mit is jelent.

3. táblázat. Mobileszköz-használat kisgyerekkorban százalékos kimutatásban életkorra lebontva

\begin{tabular}{|c|c|c|c|c|c|c|}
\hline & 6 év & 7 év & $\mathbf{8}$ év & 9 év & 10 év \\
\hline 1. & $\begin{array}{c}\text { Wifi- hez } \\
\text { kapcsolódás }\end{array}$ & $50 \%$ & $100 \%$ & $100 \%$ & $100 \%$ & $100 \%$ \\
\hline 2. & $\begin{array}{c}\text { Alkalmazások } \\
\text { zavaró üzeneteit } \\
\text { kikapcsolja }\end{array}$ & $0 \%$ & $16,7 \%$ & $41,2 \%$ & $51,2 \%$ & $87,5 \%$ \\
\hline 3. & $\begin{array}{c}\text { Le tudja védeni a } \\
\text { telefont PIN-el }\end{array}$ & $0 \%$ & $0 \%$ & $76,5 \%$ & $88,2 \%$ & $87,5 \%$ \\
\hline 4. & $\begin{array}{c}\text { Le tudja tiltani a } \\
\text { nemkínánt } \\
\text { alkalmazásokat }\end{array}$ & $0 \%$ & $0 \%$ & $0 \%$ & $0 \%$ & $12,6 \%$ \\
\hline 5. & $\begin{array}{c}\text { Ki tudja } \\
\text { kapcsolni a } \\
\text { telefon földrajzi } \\
\text { helyzetazonosító } \\
\text { funkcióját }\end{array}$ & $0 \%$ & $33,3 \%$ & $35,3 \%$ & $51,2 \%$ & $87,5 \%$ \\
\hline
\end{tabular}

\section{2. Összefüggések a szülői nevelési stílus és digitális eszközhasználat között}

A vizsgálatban részt vett szülők nevelési stílusaira vonatkozó adatokat a 4-es táblázatban láthatjuk. Amint a módszerek és eszközök részben azt részletesen bemutattuk, a szülök egy 5 pontos Likert skálán kellett a válaszlehetőségeket jelöljék. Az eredmények azt mutatják, hogy a kérdőívet kitöltő szülőkre főleg a mérvadó nevelési stílus a jellemző (maximális ponthatár 135, felezési ponthatár 67,5). A tekintélyelvủ stílus esetében a szülők által mutatott átlag arra vall, hogy nem a tekintélyelvüség jellemző rájuk a nevelésben (maximális pontszám 100, a felezési ponthatár 50), ami pedig az engedékenységet illeti, ebben az esetben is a felezési ponthatár alatt vannak az átlagok, mint az anyák, mint az apák esetében (maximális ponthatár 75, felezési ponthatár 37,5). Pozitív korreláció van az anya és az apa nevelési stílusa között $((\mathrm{p}<0,05 ; \mathrm{r}=0,7)$.

4. táblázat. A szülők nevelési stílus kérdőív faktorjainál elért átlagértékei

\begin{tabular}{|c|c|c|}
\hline & $\begin{array}{c}\text { Anya* } \\
\text { (átlag/szórás) }\end{array}$ & $\begin{array}{c}\text { Apa } \\
\text { (átlag/szórás) }\end{array}$ \\
\hline Mérvadó & $100,92 *( \pm 16,06)$ & $90,64( \pm 20,9)$ \\
\hline Tekintélyelvü & $42,10^{*}( \pm 7,4)$ & $37,5( \pm 7,3)$ \\
\hline Engedékeny & $34,40 *( \pm 10,4)$ & $31,21( \pm 5,2)$ \\
\hline
\end{tabular}

*p< 0.05 - pozitív korreláció van az anya és apa nevelési stílusa között 
A szülők 64\%-a mérvadó nevelési stílust alkalmaz, ami azt jelenti, hogy érzelmileg megértő és melegséget áraszt, bevonódik a gyerek életébe, támogatja őt, meghallgatja, türelmes és nyugodt, amikor a gyerekéről van szó, illetve demokratikusan kezeli és bevonja a gyereket a családi döntésekbe. Csupán 14,3\%-a autoriter (4 szülő), ők megmondják a gyereknek, hogy mit kell tennie és nem vonják be a döntésekbe, hanem úgy gondolják, hogy mivel ők a szülők, ők a felnőttek és náluk a döntés joga. 17,8\%-a szülöknek engedékeny, ami azt jelenti, hogy elkényezteti, és nagyon szabadjára engedi a gyereket, anélkül, hogy határokat szabna neki.

A mérvadó nevelési stílus $(\mathrm{p}<0,05 ; \mathrm{r}=0,6)$ illetve ennek a, melegség/bevonódás $(\mathrm{p}<0.05 ; \mathrm{r}=0,4)$, demokratikus $(\mathrm{p}<0,05 ; \mathrm{r}=0,5)$, illetve türelmesség alfaktorai $(\mathrm{p}<0,05 ; \mathrm{r}=0,4)$, pozitívan korrelálnak azzal, hogy a gyereknek van-e okos telefonja. Ugyanakkor a szülöi önbizalom faktorral is korreláció mutatható ki. Minél jobb a szülő megítélése a saját nevelési szokásairól, annál nagyobb az esélye annak, hogy a gyerekének van okostelefonja $(\mathrm{p}<0,05 ; \mathrm{r}=0,5)$.

Az internet használati gyakoriság korrelál az autoriter nevelési stílussal. Ha egy szülő autoriter, akkor az internet használati szokások által tudja gyereket korlátozni $(\mathrm{p}<0,05 ; \mathrm{r}=0,7)$. Ugyancsak pozitív korrelációt találtunk a gyerek hétközbeni internetezési szokásai és a szülő autoriter nevelési stílusa között. Mind a verbális osztilitás ( $\mathrm{p}<0,05 ; \mathrm{r}=0,7)$, mind a fizikai büntetés $(\mathrm{p}<0,05 ; \mathrm{r}=0,4)$, mind a direktivitás alfaktorok $(\mathrm{p}<0,05 ; \mathrm{r}=0,3)$ korrelálnak azzal, hogy a gyerek hét közben mennyit használja az internetet.

Az, hogy a gyerek hétvégén mennyit használj az internetet, korrelál a demokratikus (mérvadó) nevelői stílus ( $<<0,05 ; \mathrm{r}=0,3)$, illetve a melegség alfaktorral (mérvadó) $(\mathrm{p}<0,05 ; \mathrm{r}=0,5)$. Az, hogy a gyerek rajta van-e közösségi oldalakon korrelál a rávezetés/érvelés $(\mathrm{p}<0,05 ; \mathrm{r}=0,4)$, illetve a demokratikus mérvadó ( $\mathrm{p}<0,05 ; \mathrm{r}=0,6)$ nevelési alfaktorokkal.

A mérvadó nevelési stílus korrelál a digitális kompetencia mutatókkal is: a hozzáféréssel $(p<0,05$; $\mathrm{r}=0,7)$ létrehozással $(\mathrm{p}<0,05 ; \mathrm{r}=0,4)$, megőrzéssel $(\mathrm{p}<0,05 ; \mathrm{r}=0,3)$ és a telepítéssel $(\mathrm{p}<0,05 ; \mathrm{r}=0,4)$.

\section{7. Összefoglalás}

A szakirodalomban kétfajta nézet uralkodik. Egyik, ami azt vizsgálja, hogy milyen káros hatásai vannak az online térnek, a közösségi médiának a gyermek szocializációját illetően, a másik nézet pedig azt vallja, hogy ténykényt kell elfogadnunk azt, hogy az virtuális tér jelen van a gyerekeink életében és arra kell törekedni, hogy a gyereknek az online térhez egy egészséges viszonyulást alakítsunk ki (Tari, 2011). A család, mint elsődleges szocializációs tér szerepe tehát nem más, mint rávezetni a gyereket az egészséges eszközhasználatra, egészséges határokat szabni az online térben való navigálásra és folyamatos szülői jelenlétet, érdeklődést biztosítani, amikor a gyereknek kérdései vannak a tanulási folyamatban. Taylor (2016) szerint a gyerekek digitális képességei éppúgy fejleszthetőek, mint a különböző szoftverek, egyre többet tudó változatai. A szerző 3.0-s verziónk nevezi azt a generációt, amely biztonságban mozog az egyre bonyolultabb technikai világban. Szerinte az újfajta technika helyes használatával gyermekeink eredményesebben tudnak majd élni a társadalomban. Taylor szerint a mai szülő nehezen tart lépést a technika fejlődésével, nem könnyen igazodik el a legnépszerúbb és legfrissebb újítások között, néha nincs energiája követni a változásokat és arra koncentrálni, hogy ezeknek milyen hatásuk van a gyerekükre, viszont a szülőnek ennek ellenére is kötelessége megtenni minden, ami tőle telik, hogy a gyermek által használt digitális „kütyüket” alaposan megvizsgálja.

Jelen vizsgálat eredményei ugyancsak a szülök szerepét hangsúlyozzák a gyerek digitális kompetenciáinak fejlődésében. A fent bemutatott eredmények alapján elmondható, hogy a mérvadó nevelési stílus valóban a leghatékonyabb minta arra, hogy a gyerekeknek egészséges korlátokat szabjunk, így a hipotézisünk beigazolódott. A pozitív korreláció azt mutatja, hogy azok a szülők, akik egészséges kontrollt alkalmaznak, jobban megbíznak a gyerekükben és nem féltik, tiltják az online tértől, hanem ellenkezöleg bátorítják a gyereküket arra, hogy ebben a térben minél jobban boldoguljanak. Ebből kifolyólag a mérvadó nevelői stílust alkalmazó szülő gyerekének inkább van 
saját okos-telefonja, illetve megengedi neki, hogy közösségi oldala legyen. Ugyanakkor, amiatt, hogy demokratikus nevelési elveket vallanak, ezek a szülök engedik azt, hogy hétvégén, amikor nincsenek iskolai feladatok és a gyerekeknek több a szabadidejük, az internetes oldalakon keresgéljenek, online legyenek, tudva, hogy ez nekik hasznos és fejlödhetnek ezáltal. A mérvadó nevelési stílusú szülő a digitális kompetenciák fejlesztésében is segít, és ha a gyereke kérdez, akkor tanítja és megmutatja neki, mit hogyan kell használni és milyen műveleteket kell végezni. Ha esetleg ő sem ért bizonyos dolgokat azért partner abban, hogy megértse minél jobban a gyereke által használt eszközök müködését. Minél jobb a szülő önbizalma, annál inkább bízik a gyereke ítélőképességében, és abban, hogy meg tudja neki tanítani az egészséges korlátokat.

Ezzel ellentétben, az autoriter nevelői stílust alkalmazó szülő inkább zsarolásra, büntetésre alkalmazza a gyerek online tér iránti kíváncsiságát, ezáltal meggátolva a gyerek digitális tolltartójának gazdagodását.

Hét európai országban végzett, nyolc évnél fiatalabb gyermekes családdal végzett kvalitatív kutatás eredményei (interjúk és megfigyelések alapján) arról számolnak be, hogy a szülőket a kialakult szülői nevelési stílusuk és családi értékeik vezérlik, kiterjesztve ezeket az otthoni digitális médiára is, amikor kisgyermekeik először kezükbe vesznek egy táblagépet vagy okostelefont (Chaudron és mtsai., 2015). A szülők nagy része már rendelkezik tapasztalatokkal idősebb gyermekeikkel folytatott interakcióik miatt, és úgy módosítja a szemléletét, hogy a fiatalabb gyermekek online aktivitására már jobban odafigyeljen és beavatkozzon, amikor azt látja, hogy kisgyermekei olyan módon reagálnak a digitális eszközökre, ami aggasztja őket (túl sok időt töltenek egy tevékenységgel, bámulják a képernyőt, rosszul viselkednek, amikor elveszik az eszközt stb.). Az iskoláskorú gyermekekre összpontosítva a kutatás öt fö stratégiáját azonosított, mely által a szülöi mediálás segíthet a gyerek digitális müveltségének fejlődésében. Ezeket faktoranalízissel fejlesztették ki először az Egyesült Királyságban (Livingstone és Helsper, 2008), majd kiterjesztették 25 országra (Livingstone és mtsai., 2011). A szerzők a következő stratégiákat határozták meg:1.- az internethasználatról való aktív társalgás a gyermekkel, az internetes tartalmakról és az online tevékenységekről való beszélgetés, a közelben ülés, miközben a gyermek online van, és a gyermek online tapasztalatainak aktív megosztásának teret adni. 2.- az internet biztonságának aktív közvetítése, vagyis olyan tevékenységek ajánlása a gyereknek, amely az internet biztonságosabb és felelősségteljesebb használatának előmozdítására buzdítja őt. 3.- olyan szabályok meghatározása, amelyek korlátozzák az online eltöltött időt, a használat helyét, valamint a tartalmat és a tevékenységeket. 4.- müszaki korlátozások: szoftverek és technikai eszközök használata a gyermekek online tevékenységeinek szürésére, korlátozására és figyelemmel kísérésére. 5.- monitorozás: a gyermekek online gyakorlatának ellenőrzése használat után.

A Baumrind (1991) szülői stílusok elméletére alapozva, Valcke és munkatársai (2010) vizsgálatukban azt találták, hogy a mérvadó szülők hajlamosabbak kombinálni a mediálási stratégiákat - beleértve az aktív mediálást, a társadalmi korlátozásokat és a technikai korlátozásokat -, minta más nevelési stílusokat alkalmazó szülők. Ugyanakkor a vizsgálatukból az is kiderül, hogy a szülők iskolai végzettsége is egy befolyásoló tényező. Minél alacsonyabb iskolai végzettsége van egy szülőnek, annál kevesebb melegséget és támogatást nyújt és kevesebb ellenőrzést is gyakorol. Ezzel összefüggésben Nikken és Schols (2015) arról írnak, hogy az alacsonyabb iskolai végzettségű szülők, kevésbé jártassak a digitális média használatában, így kevésbé vesznek részt aktívan gyermekeik internethasználati szokásaik szabályozásában, következetlen szabályokat állapítanak meg a használat szabályozására, és gyakrabban alkalmaznak technikai korlátozásokat. A szülői háttér és a szülők saját tapasztalatai, valamint a digitális médiával kapcsolatos attitüdjeik hatással vannak arra, amit a szülők gyermekeiknek közvetítenek a digitális média használatáról (Hollingworth és mtsai, 2011; PausHasebrink és mtsai, 2013; Correa, 2014). A kapott eredmények nyomatékosítják azt, hogy az életkor elörehaladtával a kisgyerekek digitális kompetenciái egyre fejlettebbek lesznek, viszont a szülöi asszisztálásra mindvégig szükség van, mert nehezen tudják megítélni, szürni a káros hatásokat, így az ezzel kapcsolatos általunk megfogalmazott feltételezések is beigazolódtak. 
A kapott eredmények arra mutatnak rá, hogy milyen fontos szerepe van a családnak a gyerek digitális szocializációjában is. Fontos lenne a következőkben részletesebben kutatni ezt a kérdést. Fontos lenne kiterjeszteni a fenti kutatást egy nagyobb populációra is az adatok általánosíthatósága miatt.

\section{Irodalomjegyzék}

Baumrind, D. (1991): Parenting styles and adolescent development. In: Brooks-Gunn, J., Lerner, R., Petersen, A.C. (eds.): The encyclopedia of adolescence, Garland, NewYork

Becker, W. C. (1964): Consequences of different kinds of parental discipline. In: Vargáné dr. Nagy Ildikó (2017). Családi nevelés 2. Didakt.

Chaudron, S., Beutel, M.E., Černikova, M., Donoso Navarette,V., Dreier, M., Fletcher-Watson, B., Heikkilä, A.-S., Kontríková, V., Korkeamäki, R.-L., Livingstone, S., Marsh, J., Mascheroni, G., Micheli, M., Milesi, D., Müller, K.W., Myllylä-Nygård, T., Niska, M., Olkina, O., Ottovordemgentschenfelde, S., Plowman, L., Ribbens, W., Richardson, J., Schaack, C., Shlyapnikov, V., Šmahel, D., Soldatova, G. and Wölfling, K. (2015): Young children (0-8) and digital technology: A qualitative exploratory study across seven countries. JRC 93239/EUR 27052.

Correa, T. (2014): Bottom-up technology transmission within families: exploring how youths influence their parents' digital media use with dyadic data. Journal of Communication, 64(1), 103124.

Cole, M. Cole, S. (2006): Fejlödéslélektan, Osiris Kiadó, Budapest

Diefenbach, S. (2018): The Potential and Challenges of Digital Well-Being Interventions: Positive Technology Research and Design in Light of the Bitter-Sweet Ambivalence of Change. Frontiers in Psychology, 13(9),331-342.

Európai Bizottság jelentése (2010). Európai digitális menetrend. Memo 10/200, Brüsszel. www.ec.europa.eu

Hollingworth, S., Mansaray, A., Allen, K. and Rose, A. (2011): Parents' perspectives on technology and children's learning in the home: social class and the role of the habitus. Journal of Computer Assisted Learning 27(4), 347-360.

Livingstone, S. and Helsper, E.J. (2008): 'Parental mediation of children's internet use.' Journal of Broadcasting \& Electronic Media, 52(4), 581-599.

Livingstone, S., Haddon, L., Görzig, A. and Ólafsson, K. (2011): Risks and safety on the internet: The perspective of European children. Full findings. EU Kids Online, LSE, London

Lyons, A. (2006): Health Psychology, Cambridge, New York

Nikken, P. and Schols, M. (2015): How and why parents guide the media use of young children. Journal of Child and Family Studies, 5-8.

Ohler, J. B. (2012): Digital Community, Digital Citizen. Corwin, London, United Kingdom

Ollé J. (2012): Pedagógiai kultúra az információs társadalomban. In: Ollé J.-Papp-Danka A.-Lévai D.- Tóth-Mózer Sz.-Virányi A. (2012): Oktatás-informatikai módszerek. Tanítás és tanulás az információs társadalomban. ELTE Eötvös Kiadó, Budapest

Paus-Hasebrink, I., Bauwens, J., Dürager, A. and Ponte, C. (2013): Exploring types of parent-child relationship and internet use across Europe. Journal of Children and Media 7(1), 114-132.

Ribble, M. (2012). Digital citizenship in schools. British Journal of Educational Technology, Vol. 43 (6), 179-189.

Ranschburg Jenö (1998): Szeretet, erkölcs, autonómia. Okker Kiadó

Ranschburg, J. (2007): Rögök az utakon. Egyén és család - pszichológiai írások. Saxum, Budapest

Ribble, M., Bailey, G. (2007): Digital Citizenship is Schools. International Society for Technology in Education, Washington 
Robinson, C., Mandleco, B., Olsen, S., Hart., C. (1995). Authoritative, authoritarian, and permissive parenting practices: development and new measures. Psychological Reports, 77, 819-830.

Schaefer, E. S. (1959). A circumplex model for maternal behavior. The Journal of Abnormal and Social Psychology, 59(2), 226-235.

Tari, A. (2011): Z generáció, Tericum, Budapest

Taylor, J. (2016): A digitális nemzedék nevelése. Hogyan válhat gyermeke tudatos médiafogyasztóvá. Móra Könyvkiadó, Budapest

Vajda Zs., Kósa É. (2005): Neveléslélektan. Osiris Kiadó, Budapest

Valcke, M., Bontea, S., de Wevera, B. and Rotsa, I. (2010): Internet parenting styles and the impact on internet use of primary school children. Computers \& Education, 55(2),454-464.

\section{Szerző}

Krizbai Tímea, Sapientia - Erdélyi Magyar Tudományegyetem, Alkalmazott Társadalomtudományok Tanszék, Marosvásárhely (Románia).E-mail: timea.krizbai@gmail.com 
